\title{
O caminho virtuoso das escolas paroquiais nas frentes agrícolas no Sul do Brasil: impactos da Lei da Nacionalização de 1938
} The virtuous path of parish schools in agricultural fronts of Southern Brazil: impacts of the Nationalization Law in 1938

Paulino Eidt ${ }^{*}$

Palavras-chave: Escola Paroquial Frentes Agrícolas Nacionalização.

Keywords: Parish School Agricultural fronts Nationalization

\begin{abstract}
Resumo: Vivemos em um tempo marcado por uma crise de paradigmas, em que não somente a ideia de verdade e a forma de acesso ao saber entram em crise, como também os ideais educacionais. O cenário do século XXI reclama respeito para com a diversidade e a singularidade, opondo-se à lógica da homogeneização. Ao abrir possibilidades de conciliação e mediação, rompe com antigos paradigmas da história da educação brasileira: trata-se de reminiscências que impedem que sejamos justos com o Outro. A educação no Brasil possui um histórico excludente e avesso a uma concepção laica. A lentidão no trato do ensino público contribui para a organização da escola paroquial em alguns estados brasileiros durante o século XIX e XX, que no seu ideário, possuíam elementos de segregação. A presente pesquisa teórica e documental acompanha a trajetória das escolas paroquiais nas frentes agrícolas da região Sul do Brasil e se atém mais especificamente à periodização destas no Oeste de Santa Catarina e no município de Itapiranga/SC. No final, retrata nuances da extinção destas escolas pela Lei da Nacionalização em 1938.
\end{abstract}

\begin{abstract}
We are living a time of a crisis of paradigms, in which not only the idea of truth and the way of access to knowledge reach crisis, but also the educational ideals. The 21 st century scenario claims respect for diversity and singularity, opposing to the logic of homogenization. By opening conciliation and mediation possibilities, it breaks old paradigms of the history of the Brazilian education: they are reminiscences that preclude being fair to the Other. The education in Brazil has a history that is excluding and averse to a laic conception. The slowness in the arrangement of the public education had contributed for the organization of the Parish School in some Brazilian states during the 19th and the 20th centuries, which in its ideology had segregation elements. This theoretical and documental research follows the trajectory of parish schools in agricultural fronts of Southern Brazil and sticks more specifically to their periodization in the Western Santa Catarina and in the municipality of Itapiranga/SC. At the end, it depicts nuances of the extinction of these schools by the Nationalization Law in 1938.
\end{abstract}

Recebido em 06 de setembro de 2018. Aprovado em 11 de março de 2019.

\section{Introdução}

A educação escolar possui um histórico voltado à estratificação e dominação social. No Brasil, as oligarquias do período colonial e monárquico estavam fundamentadas na dominação via controle do saber e os modelos escolares foram uma importação europeia.
A história da educação no Brasil revela o quanto tem sido emblemática a implantação do ensino público universal. A lentidão no trato da educação pelo Estado brasileiro aumentou a importância da organização da escola paroquial em alguns estados brasileiros durante os séculos XIX e XX. A iniciativa comunitária, ainda que ideologicamente submissa ao poder religioso, foi

\footnotetext{
* Doutor em Ciências Sociais pela Pontifícia Universidade Católica de São Paulo. Exerceu docência no Ensino Superior de 1998 a 2017. Atualmente, é professor da Rede Pública de Santa Catarina. E-mail: <paulinoeidt1@gmail.com>.
} 
fundamental para a alfabetização das crianças, frente a um modelo escolar nacional excludente e eminentemente elitizado.

A presente escritura retrata nuances da escola paroquial, fruto de uma herança europeia, que acompanhou a trajetória migratória dos imigrantes, por vários séculos. As inúmeras fontes revelam facetas importantes no trato da educação escolar em espaços de colonização a partir da iniciativa comunitária.

A pesquisa teórica e documental acompanha a trajetória da instalação das escolas paroquiais nas frentes agrícolas da região sul do Brasil, no século XIX e se atém, mais especificamente, à periodização destas escolas no Oeste de Santa Catarina e no município de Itapiranga/SC, já no século XX, culminando com a extinção oficial destas pela Lei da Nacionalização, em 1938.

Nessa acepção, pretende-se, a partir das reflexões, contribuir para a reconstituição do itinerário dessas escolas, organizadas e regidas coletivamente por intermédio da comunidade. A escola paroquial, embora acompanhada de elementos controversos e de segregação, no seu devido tempo, correspondeu ao ideal daqueles que compõem a comunidade escolar - administradores, professores, estudantes, familiares e comunidade do entorno.

\section{Escolas paroquiais: alicerce da educação no Sul do Brasil}

Durante o período medieval, em virtude da ausência de Estados Nacionais politicamente instituídos e organizados que assumissem práticas e modelos educacionais, a organização de estudos com formato de escola limitava-se à formação eclesiástica (ad hoc). Desvinculada da estrutura estatal, a escola foi primeiramente pensada e executada como instituição comunal e confessional.

A ausência de fontes confiáveis acerca dos primórdios da escola paroquial geram controvérsias quanto à sua origem. Conforme Franca (1948, p. 344, grifos do autor), um dos precursores da escola confessional foi o Bispo Teodolfo de Orléans, no século VIII, ao baixar o seguinte decreto:
Os sacerdotes mantenham escolas nas aldeias e nos campos; se qualquer (quislibet) dos fiéis lhes quiser confiar os seus filhos para aprender as letras, não os deixem de receber e instruir, mas ensinem-lhes com perfeita caridade. Nem por isso exijam salário ou recebam recompensa alguma, a não ser, por exceção, quando os pais voluntariamente a quiserem oferecer por afeto ou reconhecimento.

A educação estritamente cristã, produto da Idade Média, no entanto, não foi universal e sim concebida dentro de um pensamento dualista. Instalada nos espaços privados da igreja, o ensino foi ministrado por sacerdotes encarregados de uma paróquia, preferencialmente, para postulantes à vida religiosa. Philippe Ariés (1973, p. 117) destaca a orientação e a proposta pedagógica das escolas confessionais: "Esses educadores eram responsáveis pela salvação da alma das crianças, pelas quais eles eram responsáveis perante Deus".

Essas características foram mencionadas no $3^{\circ}$ concílio ecumênico de Latrão, reunido em 1179, no seu cânon 18:

A Igreja de Deus, como mãe piedosa tem o dever de velar pelos pobres aos quais pela indigência dos pais falecem os meios suficientes, a fim de que possam facilmente estudar e progredir nas letras e nas ciências. Ordenamos, portanto, que em todas as igrejas catedrais se proveja um benefício conveniente a um mestre, encarregado de ensinar gratuitamente aos clérigos dessa igreja e a todos os alunos pobres. (FRANCA, 1948, p. 345).

Independentemente da data de origem, seja na Idade Antiga ou Média, as escolas paroquiais atravessaram a história como espaços de alfabetização, formação religiosa, expansão e consolidação da fé. Esse formato de escola, especificamente na Europa, recebeu grande impacto com as ideias iluministas que culminaram na Revolução Francesa (XVIII), pois trouxe para o espaço público e laico a proposta de uma escola ideologicamente desinteressada.

O surgimento de uma rede pública de escolas gerou desconforto e o rompimento entre o 
Estado e a Igreja. Especificamente na Prússia (hoje Alemanha), as reformas sociais e políticas que ocorreram no início do século XIX culminaram com o pensamento da universalização da escola laica. Kreutz (1994) destaca aquele período como sendo o do fortalecimento do pensamento de que a educação para todos era a condição básica para regenerar a sociedade e assegurar, a todas as crianças, o desenvolvimento intelectual.

No Brasil, este pensamento foi introduzido a partir de 1772, quando, oficialmente, foi implantado o ensino público oficial e laico pela Reforma Pombalina. O pretexto da reforma foi tirar a educação das mãos dos jesuítas e garanti-la a todos os cidadãos. Embora houvesse prerrogativas legais para universalizar a escola pública no Brasil, esta se limitou a uma parcela elitizada da população. Aranha (2008) destaca que dados oficiais de 1867 (mais de um século depois da implantação da escola pública no Brasil), apontam que apenas 10\% da população em idade escolar se matricularam nas escolas primárias e, em 1890, o nível de analfabetismo da população brasileira era de $67,2 \%$.

$\mathrm{Na}$ história ocidental, a universalização gradual da escola pública, na maioria dos países europeus no século XIX, coincidiu com a maciça emigração do velho continente. Fatores econômicos e sociais forçaram o fluxo migratório, em especial, para as frentes agrícolas do sul do Brasil. Conforme Kreutz (1994), a época inicial da imigração teuta, no Rio Grande do Sul, coincidiu com "[...] a maré alta da implantação generalizada da escola elementar na Prússia, a renovação de métodos, a formação de professores e de escolas normais e a formação da mística em torno da educação como meio de reconstrução nacional" (KREUTZ, 1994, p. 18).

Entre os fatores de atração de emigrantes europeus, em especial alemães e italianos, destacam-se: acesso fundiário, aspectos climáticos e motivações por questões estratégicas. Em todo o sul do Brasil, formaram-se comunidades rurais compostas de um número maior ou menor de famílias de proprietários com acentuada integração religiosa, social e cultural. A instalação de escolas paroquiais (denominadas assim por funcionar em pavimentos anexos a igrejas ou catedrais ou no próprio prédio em que eram realizadas celebrações) com conotações étnicas e confessionais foi uma mostra da solidez com que esse modelo adquiriu e sobreviveu a todas as vicissitudes da Idade Média e moderna. Esse modelo escolar, embora tenha sido implantado em muitas nacionalidades europeias, teve maior receptividade na Alemanha e Itália, em face do movimento conservador e manifestadamente contrário ao liberalismo e à laicização das instituições, propagado no Velho Continente.

A educação escolar ofertada nas frentes agrícolas, em especial na região sul, foi a proporcionada pelas escolas confessionais. A cultura escolar foi implantada com relativa facilidade nos espaços de ocupação de descendentes europeus, uma vez que no velho continente essa prática fazia parte do cotidiano das famílias. A formação de núcleos rurais ética e religiosamente homogêneos tem sido apontada como responsável pelo sucesso da escola paroquial:

Só com o ensino constante e efetivo das verdades da nossa santa religião, com os conselhos oportunos, com a direção prudente e com os sacramentos, precedidos da competente preparação e repetidos com discreta frequência, procuramos formar uma geração verdadeiramente cristã e forte, para resistir aos assaltos do inferno, que luta e peleja por nos arrancar a fé, levar-nos ao vício e à perdição. (HEERDT, 1992, p. 78).

O modelo escolar foi pensado e aplicado pelos jesuítas e pelo professor, mapeado criteriosamente pela comunidade e paróquia. Exigiam-se mestres com responsabilidade moral e intelectual. Ser professor tratava-se de uma missão nobre, pois este era investido de poderes de correção, punição e sabedoria. Com extensas funções sociais na comunidade, em última análise, também era responsável pelo comportamento de seus alunos fora da sala de aula.

A escola foi, em primeiro lugar, pensada, projetada, executada, implantada e cultivada como uma instituição essencialmente comunal. Sua tarefa se resumia em atender às necessidades imediatas da 
comunidade em que se encontrava, disso decorrem suas características institucionais ímpares e de perfil didático-pedagógico único (RAMBO, 1988, p. 18).

Nesse sentido, pode-se afirmar que o emigrante alemão traz consigo a convicção de que a educação escolar é fundamental e necessária para garantir às crianças o seu desenvolvimento moral e intelectual.

\section{O papel da comunidade e da religião na escolarização}

Nas frentes agrícolas das antigas colônias de imigração alemã, italiana e polonesa, do século XIX e XX, no Rio Grande do Sul e de Santa Catarina, formou-se um modelo educacional desvinculado da estrutura do Estado. Povos isolados geográfica e culturalmente, por intermédio de ações coletivas, instalaram e mantiveram um modelo comunitário de educação. A experiência das escolas paroquiais, embora instituídas com elementos de segregação, constituiu-se um sistema virtuoso. Em uma época em que a grande maioria dos brasileiros era analfabeta, as regiões de migração no sul do Brasil apresentaram taxas de escolarização próximas de $100 \%$.

As comunidades desassistidas pelo Estado brasileiro tiveram, por mais de um século, na escola paroquial (particular) elementos identitários suficientemente fortes para a manutenção do sistema escolar herdado culturalmente dos antepassados. O acompanhamento sistemático que as congregações religiosas, em especial, a Companhia de Jesus, exercia sobre os núcleos coloniais foi elemento importantíssimo para a congregação de esforços que culminassem em um modelo comunitário de vivência.

O associativismo tem sido estratégico para a consumação de um modelo comunitário de educação. A construção de vínculos sociais e uma identidade coletiva permitiu, a partir dessa relação intersubjetiva, a formação do sujeito dependente do contexto com o qual ele se relacionava interativamente. Não foi uma relação da esfera individual, e sim coletiva. $\mathrm{Na}$ comunidade, construíam-se as noções de sentidos da escola e o estreitamento da relação com o saber. A intensidade dessa relação dependeu muito do grau de integração e associação entre as famílias, a escola e a comunidade. Kreutz (2004) destaca que, em 1930, somente no estado do Rio Grande do Sul havia 1.200 escolas paroquiais alemãs.

A existência de uma comunidade pressupõe que um número considerável de pessoas tenha coisas em comum, que se "considerem" ou se "imaginem" integrantes desse grupo. Nessa acepção, dispositivos e significados adquirem forças, quando partilhados por todos. Assim, a escola paroquial, antes de ser algo impositivo foi, sobretudo, desejada pela comunidade e passou a ser um traço constitutivo de distinção cultural das colônias europeias no Sul do Brasil. Essa forma de fazer educação teve seu ápice na segunda metade do século XIX e foi oficialmente extinta com a promulgação da Lei da Nacionalização, em 1938. Embora acompanhada de um caráter controverso (etnicamente organizada), a escola paroquial assistiu a totalidade dos componentes das comunidades. Assim, em um período em que a sociedade comungava da ideia que às mulheres bastava a instrução de noções de prendas domésticas e boas maneiras, elas também eram assistidas pela escola paroquial.

Conforme Kreutz (1994), as principais características da escola paroquial foram mantidas mesmo após a Nacionalização das escolas, em 1938. As dificuldades estruturais, como ausência de prédios escolares públicos, especialmente, na fase compulsória da nacionalização, não significou o fechamento e o fim das escolas teuto-brasileiras. Em um primeiro momento, grande parte dessas escolas recebeu subvenção municipal, mantendo certa autonomia administrativa. Já em um segundo momento, essas escolas foram municipalizadas, isto é, tornaram-se escolas públicas. Estabeleceram-se acordos entre prefeituras e comunidades.

$\mathrm{O}$ estado e o município passaram a assumir parte do ônus com o magistério. "As comunidades mantinham a residência e as benfeitorias da terra da comunidade, postas para o usufruto do professor que, em compensação, prestava serviços sócio religiosos e culturais à comunidade" (KREUTZ, 1994, p. 31).

As reminiscências de um modelo de educação milenar, notadamente persistiram e 
se mantiveram nas entranhas da educação até a atualidade.

\section{Escola paroquial no Oeste de Santa Catarina}

A escola paroquial acompanhou o processo migratório da cultura alemã. Assim foi na onda imigratória do século XIX e, mais tarde, no povoamento de novas frentes agrícolas, já no século XX. A interiorização e formação de novos núcleos agrícolas, dentro e fora do estado do Rio Grande do Sul (saída das colônias velhas e formação de colônias novas) serviram para atender às diretrizes do projeto de restauração desenvolvido, em especial, pela igreja católica. Conforme Kreutz (2004), isso significou a restauração das forças religiosas contrárias ao liberalismo e à laicização das instituições. Nas novas frentes agrícolas, revigoraram-se práticas religiosas já em desuso ou contestadas no interior das antigas colônias.

Respeitadas as peculiaridades, o povoamento da região de Oeste de Santa Catarina foi um prolongamento da expansão cultural e migratória do Rio Grande do Sul. Nesse entendimento, a comunhão com aspectos culturais do estado catarinense permanece frágil até a atualidade. $\mathrm{O}$ "cordão umbilical" prende a maioria das pessoas ao estado do Rio Grande do Sul e também às origens europeias.

A onda migratória do século $\mathrm{XX}$ fez surgir, em meio à selva subtropical do Oeste de Santa Catarina, um dos projetos católicos mais coesos e fechados da História do Brasil. O Projeto Porto Novo (atuais municípios de Itapiranga, São João do Oeste e Tunápolis) - criado em 1926, pela Companhia de Jesus e pela Colonizadora Sociedade União Popular (Volksverein) - acolheu, no seu interior, somente alemães de confissão católica. Nesse entendimento, toda a literatura escrita na época enaltece a homogeneização como determinante para o sucesso de empreendimento colonial. O Projeto Porto Novo foi um sonho acalentado pelos padres da Companhia de Jesus. Ao estilo dos Sete Povos das Missões, pretendia-se conquistar a pureza religiosa e cultural pelo isolamento de uma população. $\mathrm{O}$ isolamento de alemães católicos reforçou o discurso da superioridade étnica e confessional que possui desmembramentos até hoje na região.

Embora a Companhia de Jesus não tenha sido a designada no início para assumir os destinos religiosos de Porto Novo (atribuídos aos padres da Congregação Missionários da Sagrada Família, até 1931), ela teve influência direta na organização das atividades da nova frente agrícola. A criação do Projeto Porto Novo e da Sociedade União Popular (Volksverein) haviam sido iniciativas da Companhia de Jesus.

A pioneira Maria Rohde (2011) destaca o papel das escolas paroquiais na educação de Porto Novo. Aponta dois professores precursores dessa modalidade de Ensino. Conforme ela, "para a benção das novas gerações", há de se reconhecer sempre o papel inicial dos professores Willibaldo Stuelp (núcleo da vila de Porto Novo) e da professora Antônia Wiersch (Sede Capela), visto que, em meio às precárias condições e, com muito sacrifício, erigiram os alicerces da educação de Porto Novo. As primeiras comunidades que instalaram as escolas paroquiais por meio da construção das escolas-igreja foram aquelas que serviram de "porta de entrada" para a colonização. Assim, em 1931, funcionavam fora da sede de Itapiranga, mais seis escolas: Linha Cotovelo, Linha Dourado, Linha Fortaleza, Linha Sede capela, Linha Chapéu e Linha Macuco. Uma comunidade era composta por cerca de 100 famílias dispostas em uma área geográfica de quatro quilômetros quadrados. As comunidades também eram denominadas e conhecidas como linhas ou picadas.

A escolha e contratação de docentes foi prerrogativa da colonizadora que por sua vez submetia os candidatos ao clero local. Exseminaristas e pessoas letradas escolhidas no meio social compunham o perfil docente.

Objetivamente, as comunidades, além de construir a escola-capela e efetuarem o pagamento em espécie de valores mensais para remunerar o professor, assumiam outras contribuições: construção da moradia e galpões; o plantio e colheita da lavoura; e destinação de donativos, como carnes, cereais e frutas. Por sua vez, cobravam do professor atividades de liderança na organização comunitária 
e no exercício de funções, como: canto coral, liturgia, catequese, toque do sino, assistência a doentes, mediação em conflitos de vizinhança e conselhos de toda a ordem. A imagem a seguir (Figura 1) é um comprovante de pagamento do professor Paroquial Felippe Loebens. O valor dos proventos, oriundo da mensalidade escolar, independia da formação e do número de alunos por docente.

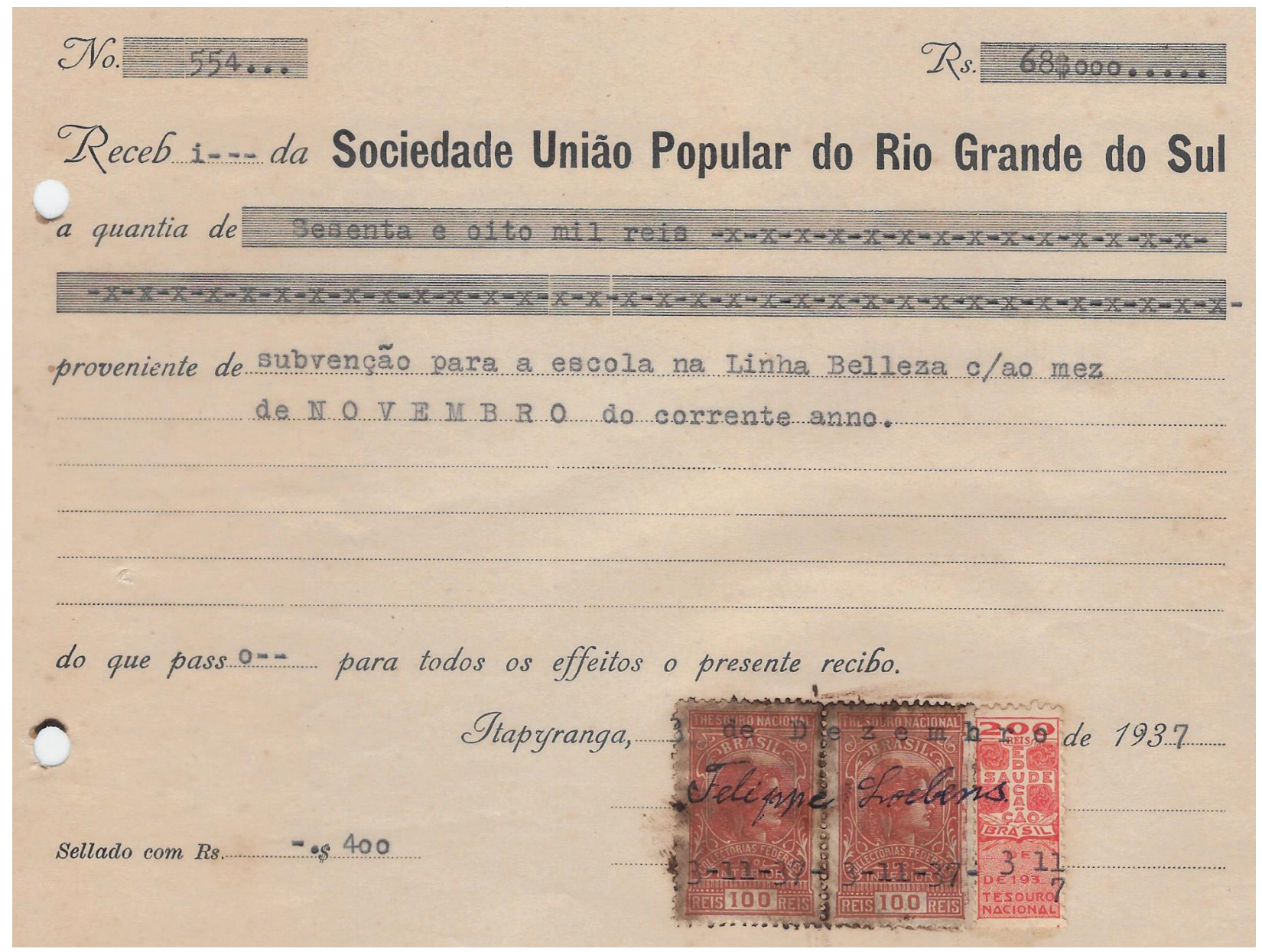

Figura 1: Recibo de pagamento do professor $^{1}$

Fonte: (PREFEITURA MUNICIPAL DE ITAPIRANGA, 1937).

A comunidade construía a escola e contratava seu professor. Assim, invariavelmente, as ações pedagógicas, os conteúdos programáticos e as bases filosóficas e ideológicas da educação estavam no controle comunitário e dos padres jesuítas. O mestre único, com múltiplas funções extraclasse, mantido e pago pelos pais, foi um personagem estratégico para a concretização do pensamento religioso dentro do universo pioneiro. $\mathrm{O}$ ato de ensinar, ao mesmo tempo em que era um prolongamento dos saberes sociais, já incitados pela família e comunidade, representava a consolidação do catolicismo como única e verdadeira religião.
A Escola paroquial X Escola pública: a fratura entre escola e religião

Ocarátermonopolista dasescolasparoquiais, não permitindo ingerência do poder público no sistema escolar, implantado pela Sociedade União Popular, em seu âmbito de domínio, no entanto, já havia sido quebrado antes de 1938. A elevação de Porto Novo a distrito de Chapecó (26 de fevereiro de 1932) inaugurou um período dos mais controversos da história local. Havia agora duas frentes de poder: o público com a nomeação de autoridades do município mãe (coletor, delegado, escrivão, 
intendente, secretário, juiz e inspetor de polícia) e o poder religioso, que se expressava, principalmente, pela Volksverein. Toda a literatura escrita da época destaca a animosidade e o mal-estar gerados entre as lideranças, especificamente, no que se refere ao conjunto de novas relações sociais, impostas pela nova estrutura administrativa sobre a tradicional, sendo esta fruto de uma herança histórica.
A imagem seguinte (Figura 2) apresenta a lista de pais contribuintes da escola paroquial. A cobrança e o recolhimento dos valores foram incumbências da colonizadora que, por sua vez, administrava os valores e fazia o repasse financeiro aos professores que atuavam nas escolas.

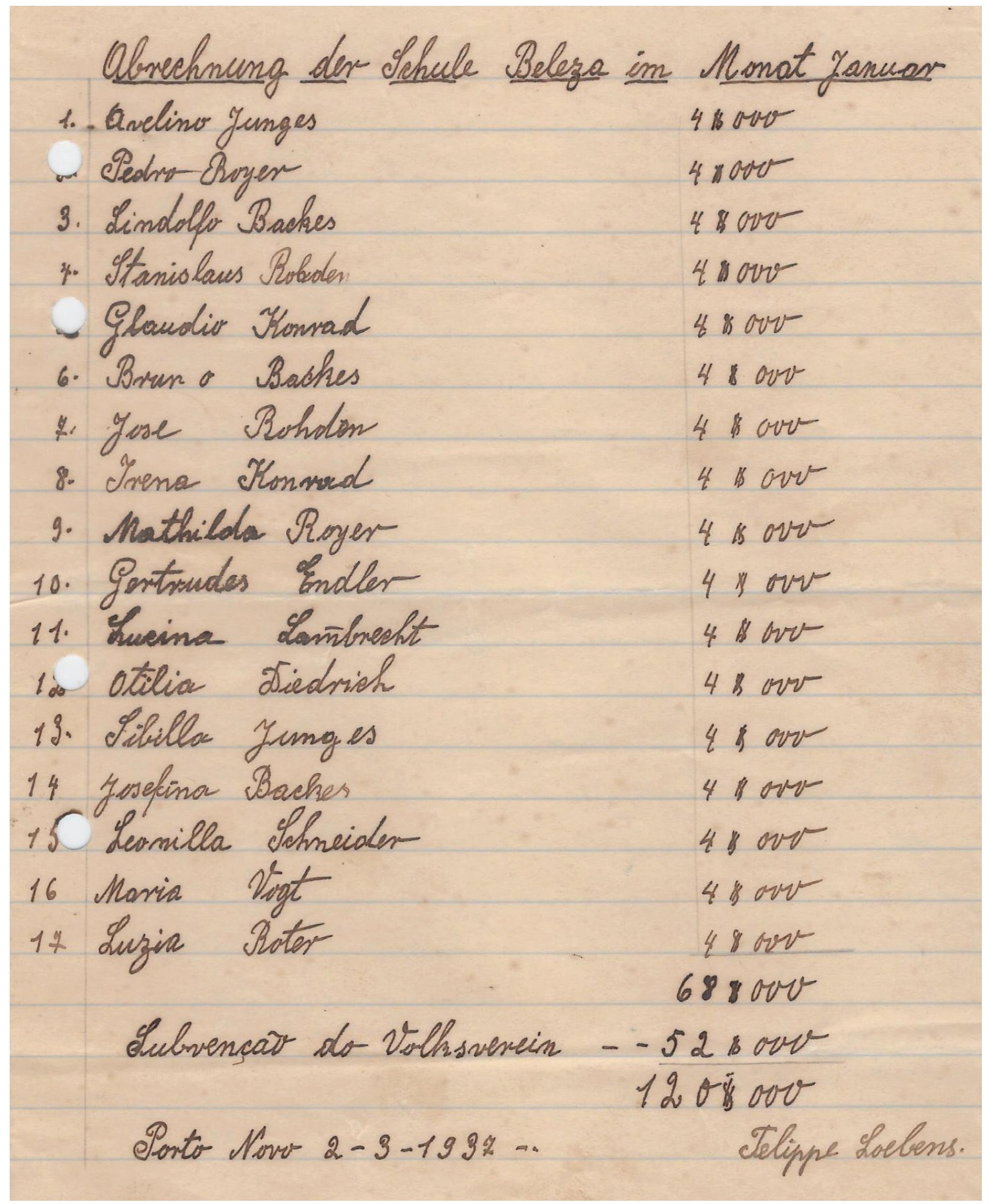

Figura 2: Controle do pagamento dos pais para a manutenção do professor paroquial Fonte: (PREFEITURA MUNICIPAL DE ITAPIRANGA, 1940) 
O novo poder instituído a partir da instalação distrital passou a condicionar a vida dos habitantes, quebrando, de certo modo, o tipo de coerência e de organização, até então predominante. Protagonista da época, o ex-professor paroquial Ervino Jaeger escreve, em sua obra (1998), que houve a instalação de uma escola pública (anterior a 1938) e nomeação de um ex-professor paroquial demitido em razão da negligência no trato das questões religiosas e da falta de moralidade. Na obra do ex-professor paroquial, este evidencia sua trajetória de formação e atuação, destacando, sobretudo, o conflito gerado a partir da Nacionalização do Ensino em 1938.

A prerrogativa de nomear e depor professores paroquiais era atribuição do pároco e da companhia colonizadora, reforçada, principalmente, no Congresso Católico de 1933. A demissão do professor paroquial foi levada a termo pelo padre; no entanto, o professor foi reconduzido à função anterior pelas mãos do escrivão distrital e, doravante, passou a ser subvencionado pelo poder público.

A remuneração do professor com recursos públicos foi um duro golpe para a manutenção de uma unanimidade no trato da escola paroquial. Como convencer as famílias endividadas pelos anos de pioneirismo a destinarem parte do seu orçamento para a manutenção da escola? As dissidências surgiam cada vez em maior número. Nesse entendimento, embora as escolas paroquiais tivessem grande simpatia entre os moradores, a não necessidade de contribuições mensais para manutenção da escola e do professor gerou alento às famílias.

Embora existissem outras escolas subvencionadas, estas subvenções eram administradas pela Volksverein e como registra o livro Tombo da Paróquia, em 1935: "A subvenção não deve tirar a índole católica, senão, ela deve ser rejeitada. Escolas subvencionadas não devem ser consideradas estatais". Nesse entendimento, a única escola pública de Porto Novo, até o período da Nacionalização (1938), foi a da sede do município, criada pelas autoridades distritais, cujo docente (Matias Walker) havia sido demitido pelo pároco por negligência no trato das questões sociais e religiosas (aos alunos da escola pública era proibida a Comunhão Solene que se constituía em uma cerimônia de conclusão da Escola Primária, acompanhada da ministração do sacramento da comunhão). Spohr (2016, p. 59) destaca uma carta do Padre Ernesto Vosskühler, dirigida ao provincial, expressando sua preocupação com o funcionamento de uma escola pública: "A escola pública enfraquece a escola paroquial. Depois de aberta a escola pública foi dado aviso na igreja que os pais católicos devem mandar seus filhos para a escola paroquial".

No entanto, a desobrigação da comunidade em assumir a totalidade dos custos da manutenção das escolas começa a ganhar força. O Livro Tombo da Paróquia registra, em 1932, um abaixo-assinado de moradores da Linha Cotovelo que se recusaram a construir o paiol para o professor. $\mathrm{Na}$ mesma direção, há um registro no Livro Tombo da Paróquia de Itapiranga de 1932, que destaca certa apatia dos alemães natos (instalados principalmente na Linha Becker) acerca das muitas contribuições exigidas para manter obras, que já eram públicas no velho continente. $\mathrm{O}$ fato é que, ao mesmo tempo em que se constituiu uma "fratura" do modelo existente até então (escola paga, professor supervisionado pela colonizadora e outros), expôs-se a emblemática dualidade de poder: Estado e religião.

Entre as muitas alegações ou pretextos para a nacionalização das escolas, algumas perpassaram todos os espaços, em especial, da região sul do Brasil, locais de predominância da imigração europeia. Trata-se da presença de nazistas nas regiões coloniais, ausência de referenciais da brasilidade e denúncias acerca da formação de "quistos étnicos". $\mathrm{O}$ regime estado-novista, que buscava construir uma pretensa identidade nacional, enxergava nessas frentes agrícolas um perigo para a unidade e homogeneização nacional. A fim de forçar a chamada identidade nacional, o presidente Getúlio Vargas, editou, em maio de 1938, o Decreto-Lei ${ }^{\circ}$ 868 , o qual determina o ensino em língua nacional e decreta o fechamento das escolas estrangeiras.

Especificamente em Santa Catarina, o nacionalismo do presidente Vargas foi levado a termo pelo Interventor Estadual Nereu Ramos. O interventor foi responsável pelo Decreto-Lei $n^{\circ}$ 88, de 31 de março de 1938, o qual estabeleceu as 
normas relativas ao ensino primário em escolas particulares. $\mathrm{O}$ decreto estabeleceu novas exigências para o registro de escolas; em suma, determinou o fechamento das escolas paroquiais, em vista da total descaracterização delas. O decreto também instituiu: professores com nacionalidade brasileira; ensino na língua vernácula; uso exclusivo da língua nacional na escrituração, uso de tabuletas, placas, cartazes, avisos, conferências, discursos, reuniões, hinos, instruções ou dísticos, na parte interna ou externa do prédio escolar. Conforme o mesmo decreto, nada pode descaracterizar o sentimento de brasilidade que deve vigorar em todas as escolas catarinenses (SANTA CATARINA, 1938a).

A repressão nacionalizadora, também pretendia controlar pela escola pública a divulgação do deutschtum (entendido como o grupo de pessoas que fala alemão como língua materna e possui características culturais específicas), evitando, dessa forma, a conservação da pureza étnica germânica, nos locais de migração. A criação de um sentimento de brasilidade também exigia da população catarinense e, em especial, das colônias de descendência europeia, o domínio dos hinos oficiais, a homenagem à Bandeira Nacional e o respeito para com os feriados nacionais.

$O$ fato pode ser deduzido a partir de uma carta encaminhada pelo inspetor escolar de Cruzeiro do Sul (atual Joaçaba), ao Palácio do Governo de Santa Catarina, em junho de 1938, onde pede o fechamento das escolas paroquiais de Itapiranga e outras:

Diante do Decreto-lei 88 que estabelece, entre outras disposições, a de que o ensino nas escolas primárias deve ser feito unicamente no vernáculo, é lamentável que crianças até a idade de 14 anos não saibam sequer uma palavra da língua do país em que nasceram. É a prova evidente e incontestável de que esta escola não cumpre as determinações de nossas leis e é um foco de antinacionalismo, o que em absoluto não podemos admitir. Assim sendo, proponho ao governo do estado que sejam aplicadas as penalidades previstas do referido Decreto-lei 88. (SANTA CATARINA, 1938b, p. 165).
O desespero da comunidade e de seus líderes religiosos, a partir da extinção das escolas paroquiais, pode ser deduzido no teor da carta encaminhada, em fevereiro de 1939, pelo Padre Francisco Riederer, ao Padre Reitor do Colégio Catarinense, em Florianópolis, solicitando a mediação junto ao governo, a fim de impedir o fechamento das escolas paroquiais e a abertura de escolas estaduais:

O governo quererá ocupar os prédios de nossas escolas paroquiais. Não o poderei permitir. É roubo. Cai sob a censura da excomunhão do Cânon 2346. Só se o governo entrar primeiro em acordo comigo, só então poderei permitir, com a condição de ser eu quem nomeia diretores e professores. Suponhamos, porém - quod Deus avertat - que o governo usurpe os prédios e os transforme em escolas estaduais e nomeie professores. Então eu proíbo a todos e qualquer um a aceitar a nomeação. Em prédios roubados da Igreja católica não vai exercer nenhuma função. As escolas-capela perderão ipso facto toda provisão canônica, não podendo fazer nelas nenhum ato de culto, nem batizados, nem casamentos, nem nada. Os sinos que houver deverão ser imediatamente retirados, nem haverá mais toque de sinos nos ditos lugares. Devemos fazer o possível para manter o ideal das escolas paroquiais. (SPOHR, 2016, p. 71).

A mediação das autoridades religiosas (o provincial e a prelazia de Palmas) junto às autoridades estaduais não teve efeito concreto e a Lei da Nacionalização das escolas foi levada a termo. O Estado exigiu professores com nacionalidade brasileira, habilitados, o ensino na Língua Portuguesa, substituição dos livros em alemão e atestado policial dos professores. Muitos dos ex-professores paroquiais se enquadraram nas novas exigências e outros largaram definitivamente o magistério. Abre-se o dilema: "como encontrar professores, com qualificação e disposição para permanecer no magistério recebendo salários módicos?".

A comunidade, ante a não assistência dos seus filhos em idade escolar, paulatinamente 
aceitou os novos rumos ditados pela Lei da Nacionalização. O vigário Padre Francisco Riederer abandonou inesperadamente a paróquia e foi substituído pelo histórico Padre Teodoro Treis. As autoridades religiosas concederam licença para que o estado ocupasse as escolas-capela, desde que a comunidade pudesse opinar junto ao inspetor escolar e este fosse religioso, acerca do aceite ou não dos novos professores estaduais, impedindo, assim, a nomeação de professores "inimigos da religião". A comunidade ainda assegurou a permanência da catequese nas escolas e, conforme relata o livro Tombo da Paróquia, de Itapiranga, em 03 de maio de 1939: "A catequese na escola deve ser ensinada em português, mas a explicação pode ser dada em alemão. Vale também para as demais matérias". A expressão "pastores espirituais", atribuída aos professores em razão do papel religioso e moral que exerciam, estava assim assegurada, mesmo na condição de docentes da rede pública de ensino.

Nessa direção, em meio à selva do então Projeto Porto Novo, acompanhado de intensas brigas e mágoas de lideranças locais, que quiseram salvar a escola paroquial, estas se deram por vencidas e uma das mais virtuosas e milenares experiências da história da educação, sucumbiu. O fim melancólico desse formato de escola foi anunciado pelo então Bispo de Palmas, Dom Carlos Eduardo de Saboia Bandeira de Mello, aos subalternos de Porto Novo, e registrado no Livro Tombo da Paróquia, em 16 de setembro de 1938: "Sino dobre finado três dias cada semana. Reúna povo todas as noites para rezar o terço na intenção das escolas [paroquiais]." Orações, apelos e boicotes à escola pública mostraram-se ineficientes ante a nova realidade. O Pároco Francisco Riederer foi a último a se dobrar e, na sua última carta ao provincial, denota sua rendição: "Nossas Escolas Paroquiais parecem irremediavelmente perdidas. Em toda a parte se abrem escolas públicas" (SPOHR, 2016, p. 69).

A Consolidação das escolas públicas, no entanto, não foi mais referenciada pelo pároco, em meio ao boicote dos prédios comunitários (escolasigreja); falta de professores públicos; sentimentos de traição de lideranças locais, este abandonou subitamente Porto Novo, em 1939. Extintas oficialmente, vertigens permaneceram por anos nas novas picadas (comunidades) que foram sendo povoadas ou em espaços já constituídos e nos quais o poder público não destinava mestres.

A Educação pública nasceu e criou força, contudo, as funções sociais e religiosas dos professores nunca foram definitivamente apagadas e, ainda, são reclamadas pela comunidade escolar, há exatos 80 anos após a extinção das escolas paroquiais.

\section{Considerações finais}

Em todo o sul do Brasil, povos isolados geográfica e culturalmente, por meio de ações coletivas instalaram e mantiveram um modelo comunitário de educação. Os núcleos foram projetados para acolher todas as formas associativas da comunidade (igrejas, clubes, escolas, cemitérios e áreas de lazer). Em meio à selva, onde a sobrevivência somente foi possível mediante a criação de um laço social horizontal, as 100 famílias, que em média compunham uma comunidade, construíram a escola, contratavam e pagavam seu professor e estabeleciam ações pedagógicas e conteúdos programáticos para seus filhos. O controle das engrenagens administrativas e as bases filosóficas e ideológicas da educação, invariavelmente, eram assumidos pela comunidade escolar.

Independentemente dos critérios adotados na implementação das escolas paroquiais, estas se constituem em uma faceta virtuosa da educação brasileira. Por um longo período, foram determinantes, ao menos para as comunidades etnicamente homogêneas, na alfabetização das crianças desassistidas pelo Estado brasileiro.

A propagação da cultura religiosa e também a ação civilizadora foram vicissitudes assumidas pela escola e pelo professor. A atividade moral e religiosa sobressaia aos ensinamentos literários, aritméticos e outros. Consciente ou inconscientemente, o papel espiritual atribuído ao professor, mostrou sua eficácia para além dos progressos da ciência. Em Itapiranga, foi determinante para frear a onda invasora de outras religiões, ao menos por mais de meio século. A atribuição de uma vasta 
função religiosa e moral ao professor fez parte de um processo de expansão e fortalecimento da fé, servindo, inclusive, no caso de Itapiranga, em um esforço para combater o protestantismo. Há, contudo, de se reconhecer que o projeto católico foi o precursor no lançamento da pedra angular da Educação no município, embora conciliando a cura das almas com o ensinar das letras.

Assim, 80 anos após a extinção das escolas paroquiais, o cenário das escolas públicas clama por tolerância religiosa e racial. É deveras complexo arquivar passivamente a herança intelectual do passado. Eis um desafio para a geração nova de professores e alunos!

\section{Notas}

$1 \mathrm{O}$ dinheiro do período 8 de outubro de 1833 a 31 de outubro de 1942 era denominado de Mil Réis (RS).

\section{Referências}

ARANHA, Maria Lúcia de Arruda. História da Educação e da Pedagogia Geral e do Brasil. 3. ed. São Paulo: Moderna, 2008.

ARIÈS, Philippe. História social da criança e da família. 2. ed. Tradução de Dora Flaksman. Rio de Janeiro: LTC, 1973.

FRANCA, Pe. Leonel S. J. A Igreja, a Reforma e a Civilização. Rio de Janeiro: Agir, 1948. Disponível em: <http://igrejareformacivilizacao.blogspot.com. br/2010>. Acesso em: 24 abr. 2018.

\section{HEERDT, Moacir. As Escolas Paroquiais em Santa}

Catarina 1890-1930. 1992. Disponível em: <http:// repositorio.ufsc.br/handle/123456789/112188>. Acesso em: 4 abr. 2018.

JAEGER, Eugênio Ervino. A Terra que eu Sonhei. Nova Petrópolis: Amstad, 1998.
PREFEITURA MUNICIPAL DE ITAPIRANGA. Livro Tombo da Escola da Linha Beleza (1930 a 1940). Itapiranga: [s. n.], 1940.

PARÓQUIA SÃO PEDRO CANÍSIO. Livro Tombo da Paróquia São Pedro Canísio (1926-1942). Itapiranga: [s. n.], 1942.

PREFEITURA MUNICIPAL DE SÃO JOÃO DO OESTE. Livro Tombo da Escola São Gabriel da Linha Ervalzinho (1930-1938). São João do Oeste: [s. n.], 1938.

KREUTZ, Lúcio. Material didático e currículo na escola teuto-brasileira. São Leopoldo: Unisinos, 1994.

KREUTZ, Lúcio. O professor paroquial: magistério e imigração alemã. Pelotas: Seiva, 2004.

RAMBO, Arthur Blásio. O associativismo teutobrasileiro e os primórdios do cooperativismo no Brasil. Porto Alegre: Eduni-Sul, 1988.

ROHDE, Maria. O Espirito Pioneiro: A herança dos antepassados. Itapiranga: Porto Novo, 2011.

SANTA CATARINA. Decreto-Lei $\mathbf{n}^{\mathbf{0}} \mathbf{8 8}$, de $\mathbf{3 1}$ de março de 1938. Estabelece normas relativas ao ensino primário, em escolas particulares no estado. Florianópolis: Imprensa Oficial, 1938a. (Coleção de decretos, leis de 1938).

SANTA CATARINA. Arquivo público. Correspondências de Diversos para o Palácio do Governo. Livro 1938, p. 165. Palmas, 19 de junho de 1938b.

SPOHR, Inácio. História das Casas: Um Resgate dos Jesuítas no Sul do Brasil. Porto Alegre: Ed. Padre Reus, 2016. 